\title{
魚肉中揮発酸の揮発に及ぼす香辛料，調味料および 食品添加物の影響
}

\author{
吉田秋比古*・佐々木清司 ${ }^{* *}$ ・森田 茂*
}

\author{
Effects of Spices, Seasonings and Food Additives on \\ Volatility of Volatile Acids from Fish Muscle
}

(Studies on Suppression of Fish Odor Part V)

\author{
Akihiko Yoshida*, Kiyoshi Sasaki** and Shigeru Morita* \\ * Osaka City Institute of Public Health and Environmental Sciences, \\ 8-34, Tojo-cho, Tennoji-ku, Osaka 543 \\ ** Osaka Aoyama Junior College, 11-1, Niina 2-chome, \\ Minoh-shi, Osaka 562
}

\begin{abstract}
Effects of 18 spices, 9 seasonings and 9 food additives on volatility of volatile acids from fish muscle homgenate were examined. Volatile acids were determined on the distillate of homogenated mixture of muscle and a test compound after distillation at $90^{\circ} \mathrm{C}$ for 30 min. Acetic acid, propionic acid, $n$-butyric acid and/or $n$-caproic acid were vaporized from the muscle homogenate of salmon, tuna, pacific saury and plaice, but hardly from that of mackerel, sea bream, sardine and yellowtail. Among the spices tested, an addition of clove to mackerel muscle released a high concentration of acetic acid, which was originated from clove itself. Increased release of volatile acids from mackerel muscle by addition of seasonings such as Worcester sauce, miso (red), tomato ketchup, white wine or vinegar originated from those in the test compounds and was probably due to decreased $\mathrm{pH}$ of the mixture by adding the test compounds. Any food additives tested had no effect on volatility of volatile acids. In the experiment with the homogenated mixture of mackerel muscle and 8 standard volatile acids, release of volatile acids was increased by an addition of clove, Worcester sauce, tomato ketchap, white wine, vinegar, ascorbic acid or sorbic acid, but decreased by that of vanillin or maltol. Cyclodextrin failed to reduce the release of volatile acids. Volatility of volatile acids was greatly influenced by $\mathrm{pH}$ of the homogenated mixture : volatile acids were hardly released about $\mathrm{pH} 6 ; n$-butyric and $n$-caproic acids were released below $\mathrm{pH} 5$; and propionic and iso-butyric acids below $\mathrm{pH} 4$.
\end{abstract}

(Received Aug. 16, 1990)

わが国の領海内で多穫されるイワシやサバなどの赤身 魚の有効利用において魚臭抑制法の開発は重要であ $3^{122)}$. 魚具の抑制に香辛料や調味料などを使用する方

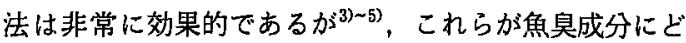

のように作用しているかを明らかにすることにより，調 理や食品加工の面で香辛料や調味料などのより合理的な

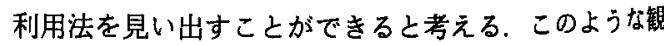
点からこれまでに魚臭の主要成分である揮発性了ミン

†魚肉の嬌臭試験（第 5 報）（前報，文献 9)）

* 大阪市立環境科学研究所（T543 大阪市天王寺区東上町 8-34）

* 大阪青山短期大学 (T562 筫面市新稲 2 丁目 11-1) 
や揮発性カルポニル化合物に対する香辛料や調味料, 食 品添加物の作用について検討してきた ${ }^{629)}$. 今回は, 揮 発性了ミンやカルボニルと同様，魚臭に大きく関わって いると考えられる揮発酸の揮発に及ぼす影響を調べた。

\section{実験材料と方法}

\section{1. 試料}

魚肉とその加工品 11 種，香辛料 18 種，調味料 9 種お よび食品添加物は市販のものを用いた（Table 1 参照）.

\section{2. 試薬}

1）揮発酸標準溶液：アセトン $1 \mathrm{~m} l$ 中に酢酸，プロ ピオン酸, イソ酪酸、 $n$-酪酸、 イソ吉草酸, $n$-吉草酸, イソカプロン酸, $n$-カプロン酸を各 $0.1 \mu l$ 溶解したも の. 重量は各揮発酸の比重を乗じて算出した.

2）残留農薬試験用アセトン: 妨害ピークの認められ ないもの（石津製薬製）。

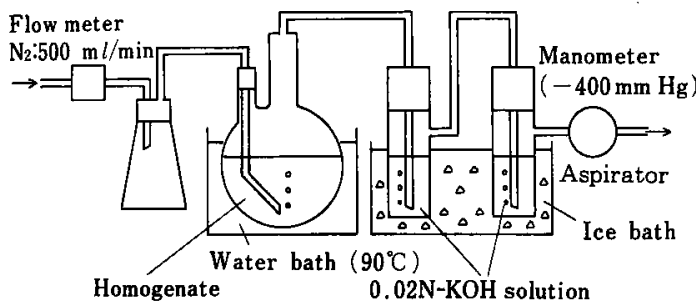

Fig. 1 Apparatus used for releasing volatile acids from fish muscle
3）吸収液： $0.02 \mathrm{~N}$ 水酸化カリウム溶液

3. 器具および装置

1）ガスクロマトグラフ：島津 GC-7 AG

2）蒸留装置 : Fig. 1 に示した.

4. 実験方法

1）試料の調製

サバ肉については約 $6 \mathrm{~kg}$ をマルチブレンダーミルで ホモジナイズし，使用直前までー $20^{\circ} \mathrm{C}$ で冷凍保存した。 供試時，電子レンジで温度上昇に注意しながら解凍した。 なお，その他の魚肉およびその加工品については供試時 にホモジナイズした

2）分析方法

武料 $50 \mathrm{~g}$ をブレンダーカップに取り，Fig. 2 に示す 上うに蒸留水 $100 \mathrm{~m} l$ を加えてホモジナイズした後，そ のホモジネートを蒸留水 $100 \mathrm{~m} l$ で $500 \mathrm{ml}$ のナス型つ ラスコに移した，それをFig. 1 に示した蒸留装置を用 いて䓨素（500 $\mathrm{m} l / \mathrm{min} ）$ を送りながらアスピレーター でー400 mmHg になるように吸引して蒸留を行なった。 蒸留温度はフラスコ内のホモジネートが十分沸騰する $90^{\circ} \mathrm{C}$ に設定し，蒸留は通常の調理加工において人間が 感じる臭いに関係する揮発酸は蒸留 30 分以内に出てく ると想定して 30 分間行なった。揮発した揮発酸を 0.02 $\mathrm{N} \mathrm{KOH}$ 溶液を入れた捕集ビンで捕集し，その捕集液 を $100 \mathrm{ml}$ のナス型フラスコに移し， $50^{\circ} \mathrm{C}$ で䕃縮乾固

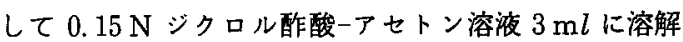
した. 生じた沈殿物をグラスウールで滤過し，その滤䘸

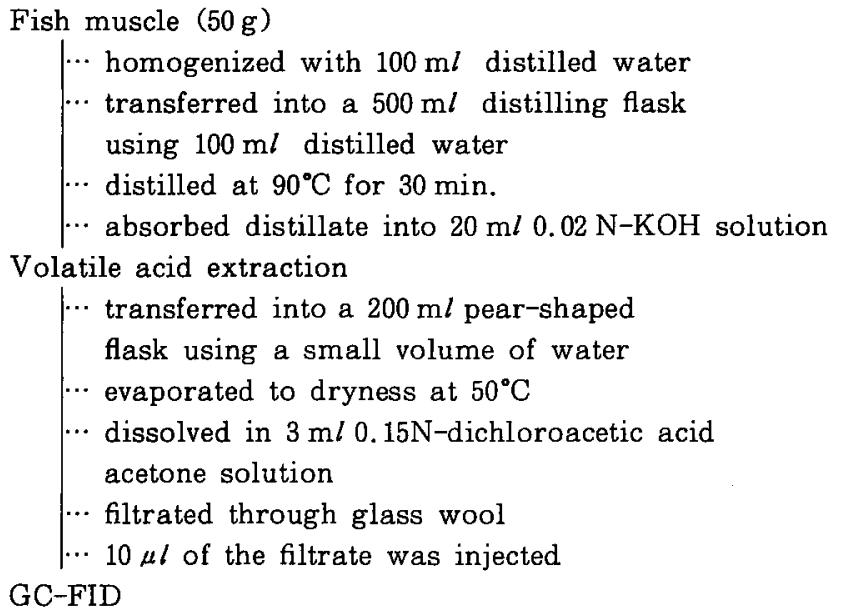

Fig. 2 Analytical method of volatile acids 
$10 \mu l$ をガスクロマトグラフィーにかけて分析した。 な お，定量は絶対検量線法で行なった。

3）ガスクロマトグラフィーの条件

カラム, ガラスカラム内径 $3 \mathrm{~mm} \times 3 \mathrm{~m}$; 充填剤, 10 $\%$ FON Celite 545 A 80 100 mesh (和光純薬工業); カラム温度, $170^{\circ} \mathrm{C}$; 注入口温度, $220^{\circ} \mathrm{C}$; 水素圧, 0.8 $\mathrm{kg} / \mathrm{cm}^{2}$; 空気圧, $0.6 \mathrm{~kg} / \mathrm{cm}^{2}$; 窒素流量, $50 \mathrm{ml} /$ 分 ; 検出器, FID.

\section{4) 嬌臭試験}

供試サバ肉 $50 \mathrm{~g}$ に香辛料 $2 \mathrm{~g}$ ，または調味料 $20 \mathrm{~g}$, または食品添加物 $100 \mathrm{mg}$ （サイクロデキストリンは 2 g）を添加し，蒸留水 $100 \mathrm{ml}$ を加えてホモジナイズし た.そのホモジネートを $100 \mathrm{~m} l$ の蒸留水で $500 \mathrm{ml}$ の 蒸留フラスコに洗い込み, 以下 Fig. 2 の行析方法に従 って揮発酸を分析した.なお，対照には何あ添加せずに 蒸留水のみを加えて調製したホモジネートを用いて同じ 条件で蒸留し，その間に揮発する揮発酸量を比較の対照 にした。

\section{5）官能検查}

4）で調製したホモジネートについて，その莫気を対 照と比較した。

6）サバ肉に添加した揮発酸の揮発に及ぼす香辛料, 調味料抢よび食品添加物の影響試験

供試サバ肉 $50 \mathrm{~g}$ に揮発酸混合液（エタノール $1 \mathrm{~m} l$ 中に酢酸，プロピオン酸，イソ酪酸， $n$-酪酸，イソ吉
草酸， $n$-吉草酸，イソカプロン酸， $n$-カプロン酸を各 $1 \mu l$ 溶解したもの）を $1 \mathrm{ml}$ 加え，さらに香辛料 $2 \mathrm{~g}$ ， または調味料 $20 \mathrm{~g}$ ，または食品添加物 $100 \mathrm{mg}$ を添加 してホモジナイズした後，嬌臭試験と同様に揮発してく る揮発酸を測定した。なお対照には揮発酸混合液のみを 加えて調製したホモジネートを用いた。

7）揮発酸の揮発に及ぼす $\mathrm{pH}$ の影響試験

供試サバ肉 $50 \mathrm{~g}$ をまずホモジナイズし，2 $\mathrm{N} \mathrm{HCI} \mathrm{ま}$ たは $2 \mathrm{~N} \mathrm{NaOH}$ で所定の $\mathrm{pH}$ に調整した後, 嬌臭試 験と同様の処理を行い，揮発酸量を測定した。また 25 $\%$ \%ン酸溶液を $20 \mathrm{ml}$ 添加してサバ肉ホモジネートの $\mathrm{pH}$ を 2 以下にし，サバ肉から揮発する揮発酸量を測定 した.

8）調味料から揮発する揮発酸の分析

調味料 $20 \mathrm{~g}$ を蒸留水 $250 \mathrm{~m} l$ に分散させ, 先と同様 に蒸留を行い，揮発してくる揮発酸量を測定した。なお， クローブは $2 \mathrm{~g}$ を同様に蒸留した。

\section{実 験 結 果}

\section{1. 魚肉およびその加工品から揮発する揮発酸量}

魚肉およびその加工品のホモジネートを $90^{\circ} \mathrm{C} て ゙ 30$ 分 間蒸留した時に揮発した揮発酸量を Table 1 に示した. 生鮮魚ではサケ，マグロ，サンマ，カレイなどで少量の 揮発酸が検出されたが，その他の魚種ではほとんど検出 されなかった，揮発酸としては酢酸，プロピオン酸、

Table 1 Volatilization of volatile acids from various fish muscles

\begin{tabular}{|c|c|c|c|c|c|c|}
\hline \multirow{2}{*}{ Fish } & \multirow{2}{*}{$\mathrm{pH}$} & \multicolumn{5}{|c|}{ Volatile acid ( $\mu \mathrm{g} / 50 \mathrm{~g}$ fish muscle) } \\
\hline & & $\mathrm{C}_{2}$ & $\mathrm{C}_{3}$ & $\mathrm{C}_{4}$ & $\mathrm{C}_{5}$ & $\mathrm{C}_{6}$ \\
\hline Mackere1 & 6.0 & ND & ND & $\mathrm{ND}$ & ND & ND \\
\hline Salmon & 6.4 & 3.0 & ND & 2.4 & ND & ND \\
\hline Tuna & 5.7 & ND & $\mathrm{ND}$ & 0.5 & ND & 1.2 \\
\hline „Pacific saury & 6.1 & 3.7 & 1.2 & 0.4 & ND & $\mathrm{ND}$ \\
\hline Mackerel (salted) & 5.7 & ND & 0.4 & ND & ND & ND \\
\hline Plaice & 6.7 & ND & 0.6 & ND & ND & ND \\
\hline Sea bream & 6.6 & ND & ND & ND & 0.2 & ND \\
\hline Sea bream (cured in miso) & 6.5 & 5.4 & ND & ND & ND & ND \\
\hline Sardine & 6.0 & ND & ND & ND & ND & ND \\
\hline Yellowtail & 5.5 & ND & ND & $\mathrm{ND}$ & ND & ND \\
\hline Horse mackerel & 6.0 & ND & $\mathrm{ND}$ & ND & ND & ND \\
\hline
\end{tabular}

Analytical method was shown in figure 2. Homogenate of $50 \mathrm{~g}$ fish muscle was distilled at $90^{\circ} \mathrm{C}$ for $30 \mathrm{~min}$. and volatile acids volatilized were measured.

$\mathrm{ND}$ : less than $0.1 \mu \mathrm{g} / 50 \mathrm{~g}$ muscle. $\mathrm{C}_{2}$ : acetic acid, $\mathrm{C}_{3}$ : propionic acid, $\mathrm{C}_{4}: n$-butyric acid, $\mathrm{C}_{5}$ : $n$-valeric acid, $\mathrm{C}_{6}: n$-caproic acid. 
$n$-酪酸、n-吉草酸， $n$-カプロン酸などが検出された。

2. サハ肉に香辛料を添加した場合に揮発する揮発酸 サバ肉のホモジネートに種々の香辛料を添加して 90 ${ }^{\circ} \mathrm{C}$ で 30 分間蒸留した場合に揮発した揮発酸を Table 2 に示した，クローブを添加した場合のみ多量の酢酸が揮 発したが，その他の香辛料では揮発酸の揮発はなかった。 なお，括胍内に示したように，クローブのみを蒸留した 場合6多量の酢酸が揮発し，さらにイソ吉草酸， $n$-カ プン酸す揮発した．魚具は香辛料が持つ強い香りによ りはとんど感じられなかった。

\section{3. サバ肉に調味料を添加した場合に揮発する揮発酸} サバ肉のホモジネートに種々の調味料を添加して 90 ${ }^{\circ} \mathrm{C}$ で 30 分間蒸留した場合に揮発した揮発酸を Table 3 に示した，ウスターソース，赤味噌，トマトヶチャップ， 白ワイン，食酢などを添加した場合に酢酸の揮発量が多 く，とくにウスターソースではプロピオン酸，イソ酪酸， nー酪酸などす揮発した。 なお，これらの調味料のみを
同様の条件で蒸留した場合もかなりの揮発酸の揮発がみ られた.すなわち括弧内に示したように，ウスターソー ス，トマトケチャップ，食酢から多量の酢酸が揮発した。 またウスターソースではプロピオン酸，イソ酪酸， $n$ 一酪酸などあ揮発した。さらに，これらの調味料を添 加した場合にホモジネートの pH が低下した. 魚臭に ついては赤味噌や靦油，食酢などを添加した場合にこれ らの調味料が持つ強い香りにより魚臭が感じられなくな った.

\section{4. サバ肉に食品添加物を添加した場合に揮発する揮 発酸}

香辛料や調味料の場合とは異なり，いずれの食品添加 物を添加した場合も揮発酸の揮発はみられなかった。

\section{5. サバ肉中の添加揮発酸の揮発に及ぼす香辛料の影}

サバ肉では揮発酸はほとんど揮発しないので一定量の 揮発酸を添加して実験を行なった。 サバ肉のホモジネー

Table 2 Volatilization of volatile acids from mixtures of mackerel muscle and spice

\begin{tabular}{|c|c|c|c|c|c|c|c|}
\hline \multirow{2}{*}{ Spice } & \multirow{2}{*}{$\mathrm{pH}$} & \multirow{2}{*}{$\begin{array}{l}\text { Fishy } \\
\text { odor }\end{array}$} & \multicolumn{5}{|c|}{ Volatile acid ( $\mu \mathrm{g} / 50 \mathrm{~g}$ mackerel muscle) } \\
\hline & & & $\mathrm{C}_{2}$ & $\mathrm{C}_{3}$ & $\mathrm{C}_{4}$ & iso- $\mathrm{C}_{5}$ & $\mathrm{C}_{6}$ \\
\hline Control (no spice) & 6.0 & 4 & ND & ND & ND & ND & ND \\
\hline Pepper & 6.0 & 0 & ND & $\mathrm{ND}$ & ND & ND & ND \\
\hline Wasabi & 5.9 & 1 & ND & $\mathrm{ND}$ & ND & ND & ND \\
\hline Clove & 5.7 & 0 & $112(551)$ & $\mathrm{ND}$ & ND & $\mathrm{ND}(6.8)$ & $\mathrm{ND}(6.1)$ \\
\hline Japanese pepper & 5.9 & 0 & $\mathrm{ND}$ & ND & ND & $\mathrm{ND}$ & ND \\
\hline Ginger powder & 5.9 & 1. & $\mathrm{ND}$ & $\mathrm{ND}$ & $\mathrm{ND}$ & $\mathrm{ND}$ & ND \\
\hline Laurel & 5.9 & 0 & $\mathrm{ND}$ & ND & ND & ND & $\mathrm{ND}$ \\
\hline Allspice & 5.9 & 0 & $\mathrm{ND}$ & $\mathrm{ND}$ & $\mathrm{ND}$ & ND & $\mathrm{ND}$ \\
\hline Sage & 6.0 & 0 & ND & $\mathrm{ND}$ & $\mathrm{ND}$ & $\mathrm{ND}$ & $\mathrm{ND}$ \\
\hline Nutmeg & 6.0 & 0 & $\mathrm{ND}$ & ND & ND & $\mathrm{ND}$ & $\mathrm{ND}$ \\
\hline Thyme & 5.9 & 0 & $\mathrm{ND}$ & $\mathrm{ND}$ & $\mathrm{ND}$ & $\mathrm{ND}$ & $\mathrm{ND}$ \\
\hline Rosemary & 6.0 & 0 & ND & $\mathrm{ND}$ & $\mathrm{ND}$ & $\mathrm{ND}$ & $\mathrm{ND}$ \\
\hline Mustard & 6.0 & 1 & $\mathrm{ND}$ & $\mathrm{ND}$ & $\mathrm{ND}$ & $\mathrm{ND}$ & $\mathrm{ND}$ \\
\hline Garlic powder & 6.0 & 0 & ND & $\mathrm{ND}$ & $\mathrm{ND}$ & ND & $\mathrm{ND}$ \\
\hline Onion powder & 6.0 & 0 & $\mathrm{ND}$ & $\mathrm{ND}$ & $\mathrm{ND}$ & $\mathrm{ND}$ & $\mathrm{ND}$ \\
\hline Curry powder & 6.0 & 0 & $\mathrm{ND}$ & $\mathrm{ND}$ & $\mathrm{ND}$ & $\mathrm{ND}$ & $\mathrm{ND}$ \\
\hline Oregano & 6.0 & 0 & ND & $\mathrm{ND}$ & $\mathrm{ND}$ & $\mathrm{ND}$ & $\mathrm{ND}$ \\
\hline Fennel & 6.0 & 1 & $\mathrm{ND}$ & $\mathrm{ND}$ & $\mathrm{ND}$ & $\mathrm{ND}$ & $\mathrm{ND}$ \\
\hline Coriander & 5.9 & 2 & $\mathrm{ND}$ & $\mathrm{ND}$ & $\mathrm{ND}$ & $\mathrm{ND}$ & $\mathrm{ND}$ \\
\hline
\end{tabular}

Homogenized mixture of $50 \mathrm{~g}$ mackerel muscle and $2 \mathrm{~g}$ spice was distilled at $90^{\circ} \mathrm{C}$ for $30 \mathrm{~min}$, and volatile acids volatilized were measured. ND : less than $0.1 \mu \mathrm{g} / 50 \mathrm{~g}$ mackerel muscle.

Fishy odor : $0=$ no odor, $1=$ indistinct, $2=$ weak, $3=$ moderate, $4=$ strong odor.

$\mathrm{C}_{2}$ : acetic acid, $\mathrm{C}_{3}$ : propionic acid, $\mathrm{C}_{4}: n$-butyric acid, iso- $\mathrm{C}_{5}:$ iso-valeric acid, $\mathrm{C}_{6}: n$-caproic acid. Volatile acid contents $(\mu \mathrm{g} / \mathrm{g})$ volatilized from $1 \mathrm{~g}$ spice itself were shown in the brackets. 
Table 3 Volatilization of volatile acids from mixtures of mackerel muscle and seasoning

\begin{tabular}{lccccccc}
\hline \hline \multirow{2}{*}{ Seasoning } & $\mathrm{pH}$ & $\begin{array}{c}\text { Fishy } \\
\text { odor }\end{array}$ & $\mathrm{C}_{2}$ & $\mathrm{C}_{3}$ & iso-C & $\mathrm{C}_{4}$ & $\mathrm{C}_{6}$ \\
\hline Control (no seasoning) & 6.0 & 4 & $\mathrm{ND}$ & $\mathrm{ND}$ & $\mathrm{ND}$ & $\mathrm{ND}$ & $\mathrm{ND}$ \\
Worcester sauce & 5.0 & 2 & $1708(860)$ & $15.3(4.8)$ & $4.4(5.6)$ & $5.5(1.3)$ & $\mathrm{ND}$ \\
Miso (red) & 5.6 & 0 & $84(4)$ & $\mathrm{ND}$ & $\mathrm{ND}$ & $\mathrm{ND}$ & $\mathrm{ND}$ \\
Miso (white) & 5.8 & 2 & $\mathrm{ND}$ & $\mathrm{ND}$ & $\mathrm{ND}$ & $\mathrm{ND}$ & $\mathrm{ND}$ \\
Tomato ke tchup & 5.2 & 2 & $205(225)$ & $\mathrm{ND}$ & $\mathrm{ND}$ & 2.1 & $\mathrm{ND}$ \\
Wine (white) & 5.6 & 2 & $59(11)$ & $\mathrm{ND}$ & $\mathrm{ND}$ & $\mathrm{ND}$ & $2.6(0.6)$ \\
Soy sauce & 5.7 & 1 & $\mathrm{ND}$ & $\mathrm{ND}$ & $\mathrm{ND}$ & $\mathrm{ND}$ & $\mathrm{ND}$ \\
Vinegar & 4.4 & 1 & $3113(1270)$ & $\mathrm{ND}$ & $\mathrm{ND}$ & $\mathrm{ND}$ & $\mathrm{ND}$ \\
Sake & 5.9 & 1 & $28(17)$ & $\mathrm{ND}$ & $\mathrm{ND}$ & $\mathrm{ND}$ & $\mathrm{ND}$ \\
Mirin & 6.2 & 2 & $\mathrm{ND}$ & $\mathrm{ND}$ & $\mathrm{ND}$ & $\mathrm{ND}$ & $\mathrm{ND}$ \\
\hline
\end{tabular}

See the note to Table 2. $20 \mathrm{~g}$ seasoning was used instead of spice.

$\mathrm{C}_{2}$ : acetic acid, $\mathrm{C}_{3}$ : propionic acid,. iso- $\mathrm{C}_{4}:$ iso-butyric acid, $\mathrm{C}_{4}: n$-butyric acid, $\mathrm{C}_{6}: n$-caproic acid. Volatile acid contents $(\mu \mathrm{g} / \mathrm{g})$ volatilized from $1 \mathrm{~g}$ seasoning itself were shown in brac-

kets.

トに 8 種の揮発酸をそれぞれ $1 \mu l$ ずつ含有する混合液 を加え, さらに香辛料を加えて $90^{\circ} \mathrm{C} て ゙ 30$ 分間蒸留した 場合の揮発酸の揮発量の変化を Table 4 に示した. 山 葵, 山极, クローブ, オニオンパウダー、ジンジャーパ ウダー、フェンネル, コリアンダーを添加した場合に揮 発酸の揮発量が対照に比べて多く，特にクローブの場合 に顕著であったが、ローレルとオールスパイスでは僅か に滅少傾向がみられた，その他の香辛料では揮発酸の揮 発を增加させることも隇少させることもなかった，ク口 ーブを添加した場合にのみ $\mathrm{pH}$ がわずかに低下した。

\section{6. サバ肉中の添加揮発酸の揮発に及ほすす調味料の影}

\section{翌}

調味料について同様に揮発酸混合液を加えて加熱蒸留 した場合の揮発酸の揮発量を Table 5 に示した. ウス ターソース, トマトケチャップ, 白ワイン, 食酢などを 添加した場合に揮発酸の揮発量が増加し，とくにイン酪 酸，イソ吉草酸などの分㞳した側鎖を持つ揮発酸の方が 直鎖のものより多く揮発する傾向がみられた．また赤味 噌では酢酸以外の揮発酸の揮発が抑制された.

7. サバ肉中の添加揮発酸の揮発に及ぼす食品添加物 の影整

食品添加物については Table 6 に示したようにアス コルビン酸とンルビン酸を添加した場合に揮発酸の揮発 量が増加し，バニリン，マルトールでは減少した．また 魚臭の抑制に効果があるといわれているサイクロデキス トリンは揮発酸の揮発を抑制する効果がみられなかった.

\section{8. 揮発酸の揮発に及ばす $\mathbf{p H}$ の影霓}

酸またはアルカリによりサバ肉のホモジネートの pH を調整した後, $90^{\circ} \mathrm{C}$ で 30 分間蒸留した時の揮発酸の揮 発量の変化を Table 7 に示した. pH 6 以上では揮発 酸の揮発はほとんどみられないが，pH 5 に下げると $n$-酪酸や $n$-カプロン酸が揮発し，さらに $\mathrm{pH} 4$ ではフ ロピオン酸やイソ酪酸む揮発した。 またリン酸で $\mathrm{pH} 2$ 以下にすると比較的多種類の脂肪酸が量的にあ多く揮発 した. 魚臭は $\mathrm{pH}$ が高くなるほど強くなり， $\mathrm{pH} 8$ 以上 では腐敗臭を呈した．Fig. 3 にサハ肉のホモジネート をリン酸で $\mathrm{pH} 2$ 以下にした時に揮発してきた揮発酸 のガスクロマトグラムを示した.

\section{考察}

今回の奏験では食品としての魚肉（pH 4〜7）から揮 発する揮発酸について検討したが，生鮮魚のホモジネー ト (pH 6 前後) から揮発する揮発酸は非常にわずかで, その揮発量は $\mathrm{pH}$ の影響試験 (Table 7) や揮発酸を添 加した試験（Table 4，5，6）からいずれの揮発酸す実 際に含まれる量のごく一部 (1\%以下) であることが分 かった. 揮発酸の揮発は前報の揮発性アミン采とは逆に $\mathrm{pH}$ が低くなる程多くなり，サバ肉では Table 7 に示 すように $\mathrm{pH}$ を調整しないそのままのホモジネート （pH 5.95）では揮発酸の揮発は見られないが, $\mathrm{pH} 5$ に下げると酪酸やカプロン酸が揮発し，pH 4 ではプロ ピオン酸やイン酪酸も揮発してきた。また，リン酸で 
Table 4 Effect of various spices on valatilization of volatile acid from mackerel muscle

\begin{tabular}{|c|c|c|c|c|c|c|c|c|c|}
\hline \multirow{2}{*}{ Spices } & \multirow{2}{*}{$\mathbf{p H}$} & \multicolumn{8}{|c|}{ Volatile acid ( $\mu \mathrm{g} / 50 \mathrm{~g}$ mackerel muscle) } \\
\hline & & $\mathrm{C}_{2}$ & $\mathrm{C}_{3}$ & iso $-\mathrm{C}_{4}$ & $\mathrm{C}_{4}$ & iso- $\mathrm{C}_{5}$ & $\mathrm{C}_{5}$ & iso- $\mathrm{C}_{6}$ & $\mathrm{C}_{6}$ \\
\hline $\begin{array}{l}\text { Control } \\
\text { (no addition) }\end{array}$ & 5.85 & 6.0 & 8.5 & 4.7 & 4.9 & 8.3 & 5.6 & 8.6 & 7.8 \\
\hline Pepper & 5.90 & 15.8 & 7.9 & 4.3 & 4.4 & 7.1 & 6.0 & 8.7 & 9.5 \\
\hline Wasabi & 5.90 & ND & 8.4 & 15.0 & 12.8 & 24.6 & 17.3 & 26.1 & 17.7 \\
\hline Japanese pepper & 5.85 & 18.4 & 7.4 & 9.0 & 9.3 & 13.7 & 10.1 & 16.3 & 19.8 \\
\hline Clove & 5.75 & 73.5 & 19.5 & 25.4 & 20.9 & 33.4 & 25.7 & 36.6 & 34.7 \\
\hline Laurel & 6.20 & 4.3 & 5.9 & 2.5 & 3.9 & 4.4 & 5.3 & 6.3 & 6.2 \\
\hline Allspice & 5.85 & $\mathrm{ND}$ & 2.5 & 2.8 & 2.4 & 3.9 & 2.0 & 5.2 & 3.9 \\
\hline Sage & 5.90 & 11.1 & 10.8 & 6.1 & 6.1 & 8.6 & 8.8 & 13.6 & 14.3 \\
\hline Nutmeg & 5.90 & ND & 6.0 & 6.3 & 5.8 & 9.5 & 7.8 & 12.1 & 12.6 \\
\hline Thyme & 5.95 & 4.4 & 7.0 & 4.2 & 5.4 & 6.0 & 6.8 & 8.8 & 10.2 \\
\hline Rosemary & 5.85 & ND & 6.5 & 8.2 & 5.5 & 8.7 & 7.5 & 11.6 & 11.6 \\
\hline Mustard & 5.90 & 6.4 & 9.2 & 3.2 & 7.4 & 6.9 & 6.7 & 7.2 & 3.8 \\
\hline Garlic powder & 6.20 & ND & 4.2 & 5.4 & 5.7 & 8.4 & 6.0 & 9.7 & 10.9 \\
\hline Ginger powder & 5.90 & 9.5 & 10.7 & 10.8 & 10.7 & 14.6 & 12.1 & 17.8 & 18.6 \\
\hline Onion powder & 6.00 & ND & 6.6 & 7.2 & 7.1 & 11.0 & 9.3 & 14.6 & 14.1 \\
\hline Curry powder & 6.05 & ND & 7.4 & 3.8 & 5.0 & 8.3 & 5.1 & 8.9 & 8.9 \\
\hline Oregano & 5.90 & 8.0 & 7.1 & 6.1 & 4.7 & 8.8 & 8.3 & 13.1 & 12.6 \\
\hline Fennel & 6.00 & ND & 5.3 & 7.5 & 7.8 & 12.4 & 10.3 & 17.5 & 15.2 \\
\hline Coriander & 5.90 & ND & 4.9 & 10.3 & 8.6 & 14.5 & 10.8 & 17.5 & 18.2 \\
\hline
\end{tabular}

One $\mathrm{m} l$ ethanol containing all volatile acids listed at $1 \mu l$ each was added to $50 \mathrm{~g}$ mackerel muscle and then $2 \mathrm{~g}$ spice was mixed. The homogenized mixture was distilled at $90^{\circ} \mathrm{C}$ for 30 min. and volatile acids volatilized were measured.

$\mathrm{ND}$ : less than $0.1 \mu \mathrm{g} / 50 \mathrm{~g}$. $\mathrm{C}_{2}$ : acetic acid, $\mathrm{C}_{3}$ : propionic acid, iso-C $\mathrm{C}_{4}$ : iso-butyric acid, $\mathrm{C}_{4}$ : $n$-butyric acid, iso- $\mathrm{C}_{5}$ : iso-valeric acid, $\mathrm{C}_{5}: n$-valeric acid, iso- $\mathrm{C}_{6}:$ iso-caproic acid, $\mathrm{C}_{6}: n$-caproic acid.

Table 5 Effect of various seasonings on volatilization of volatile acids from mackerel muscle

\begin{tabular}{|c|c|c|c|c|c|c|c|c|c|}
\hline \multirow{2}{*}{ Seasoning } & \multirow{2}{*}{$\mathrm{pH}$} & \multicolumn{8}{|c|}{ Volatile acid ( $\mu \mathrm{g} / 50 \mathrm{~g}$ mackerel muscle) } \\
\hline & & $\mathrm{C}_{2}$ & $\mathrm{C}_{3}$ & iso- $\mathrm{C}_{4}$ & $\mathrm{C}_{4}$ & iso- $\mathrm{C}_{5}$ & $\mathrm{C}_{5}$ & iso- $\mathrm{C}_{6}$ & $\mathrm{C}_{6}$ \\
\hline $\begin{array}{l}\text { Control } \\
\text { (no addition) }\end{array}$ & 5.85 & 6.0 & 8.5 & 4.7 & 4.9 & 8.3 & 5.6 & 8.6 & 7.8 \\
\hline Worcester sauce & 4.75 & 3247.7 & 55.0 & 71.6 & 51.3 & 83.9 & 58.7 & 85.2 & 76.2 \\
\hline Miso(red) & 5.50 & 134.9 & 7.2 & 1.5 & 2.8 & 0.2 & 2.7 & 2.9 & 1.5 \\
\hline Miso(white) & 5.60 & 7.0 & 5.6 & 2.6 & 4.5 & 4.9 & 4.8 & 6.2 & 4.5 \\
\hline Tomato ketchup & 5.00 & 700.6 & 28.4 & 51.0 & 34.6 & 62.7 & 44.7 & 62.8 & 56.6 \\
\hline Wine(white) & 5.45 & 233.7 & 36.2 & 67.5 & 50.6 & 82.3 & 60.0 & 87.4 & 85.3 \\
\hline Soy sauce & 5.60 & 35.1 & 12.1 & 7.0 & 7.1 & 11.1 & 9.0 & 12.8 & 13.1 \\
\hline Vinegar & 4.35 & 11335.5 & 37.8 & 88.2 & 58.5 & 110.5 & 73.5 & 102.1 & 86.9 \\
\hline Sake & 5.80 & 62.2 & 11.6 & 3.2 & 5.0 & 4.2 & 5.9 & 5.5 & 6.2 \\
\hline Mirin & 5.70 & ND & 9.4 & 10.3 & 8.3 & 15.9 & 12.2 & 18.9 & 19.0 \\
\hline
\end{tabular}

See the note to Table $4.20 \mathrm{~g}$ seasoning was used instead of spice. 
Table 6 Effect of various food additives on volatilization of volatile acids from mackerel muscle

\begin{tabular}{|c|c|c|c|c|c|c|c|c|c|}
\hline \multirow{2}{*}{ Food additive } & \multirow{2}{*}{$\mathrm{pH}$} & \multicolumn{8}{|c|}{ Volatile acid ( $\mu \mathrm{g} / 50 \mathrm{~g}$ mackerel muscle) } \\
\hline & & $\mathrm{C}_{2}$ & $\mathrm{C}_{3}$ & iso- $_{4}$ & $\mathrm{C}_{4}$ & iso- $\mathrm{C}_{5}$ & $\mathrm{C}_{5}$ & iso- $\mathrm{C}_{6}$ & $\mathrm{C}_{6}$ \\
\hline $\begin{array}{l}\text { Control } \\
\text { (no addition) }\end{array}$ & 5.85 & 6.0 & 8.5 & 4.7 & 4.9 & 8.3 & 5.6 & 8.6 & 7.8 \\
\hline Sodium nitrite & 5.90 & 5.1 & 11.3 & 7.6 & 7.4 & 9.2 & 9.5 & 9.5 & 8.7 \\
\hline Ascorbic acid & 5.70 & 5.6 & 10.5 & 9.3 & 7.8 & 13.4 & 10.9 & 16.8 & 17.1 \\
\hline Sorbic acid & 5.70 & 5.7 & 17.2 & 18.0 & 16.1 & 20.2 & 16.8 & 25.0 & 20.7 \\
\hline Vanillin & 5.80 & 4.5 & 5.7 & ND & 1.9 & ND & 0.9 & ND & ND \\
\hline Maltol & 5.80 & 6.4 & 14.7 & 0.4 & 2.3 & ND & 1.2 & 0.8 & ND \\
\hline$\alpha$-Cyclodextrin & 5.80 & 5.7 & 7.0 & 5.9 & 6.0 & 7.7 & 5.6 & 9.7 & 6.7 \\
\hline$\beta-$ Cyclodextrin & 5.90 & ND & 6.8 & 4.7 & 7.1 & 6.0 & 8.4 & 8.7 & 11.9 \\
\hline$r$-Cyclodextrin & 5.95 & ND & 5.9 & 10.3 & 13.9 & 16.1 & 12.2 & 17.9 & 17.5 \\
\hline Dextrin & 5.90 & $\mathrm{ND}$ & 4.6 & 7.2 & 4.9 & 10.5 & 7.9 & 13.2 & 13.2 \\
\hline
\end{tabular}

See the note to Table 4. One hundred $g$ of food additive ( $\mathrm{g}$ in case of cyclodextrin) was used instead of spice.

Table 7 Effect of $\mathrm{pH}$ on volatilization of volatile acids from mackerel muscle

\begin{tabular}{|c|c|c|c|c|c|c|c|c|c|}
\hline \multirow{2}{*}{ Adjusted pH } & \multirow{2}{*}{$\begin{array}{l}\text { Fishy } \\
\text { odor }\end{array}$} & \multicolumn{8}{|c|}{ Volatile acid ( $\mu \mathrm{g} / 50 \mathrm{~g}$ mackerel muscle) } \\
\hline & & $\mathrm{C}_{2}$ & $\mathrm{C}_{3}$ & iso- $\mathrm{C}_{4}$ & $\mathrm{C}_{4}$ & iso- $\mathrm{C}_{5}$ & $\mathrm{C}_{5}$ & iso- $\mathrm{C}_{6}$ & $\mathrm{C}_{6}$ \\
\hline $\begin{array}{l}\mathrm{pH} 5.95 \\
\text { (not adjusted) }\end{array}$ & 2 & ND & $\mathrm{ND}$ & ND & ND & $\mathrm{ND}$ & ND & $\mathrm{ND}$ & ND \\
\hline $\begin{array}{l}\text { pH } 1.55 \\
\text { (with phosphoric } \\
\text { acid) }\end{array}$ & 1 & 14.5 & 4.5 & 0.5 & 6.2 & 1.6 & 2.0 & ND & 7.4 \\
\hline $\mathrm{pH} 4.00$ & 1 & $\mathrm{ND}$ & 1.9 & 0.5 & 3.7 & $\mathrm{ND}$ & ND & ND & 3.7 \\
\hline pH 5.00 & 2 & $\mathrm{ND}$ & $\mathrm{ND}$ & ND & 3.6 & $\mathrm{ND}$ & ND & ND & 4.5 \\
\hline $\mathrm{pH} 6.00$ & 2 & ND & $\mathrm{ND}$ & $\mathrm{ND}$ & $\mathrm{ND}$ & $\mathrm{ND}$ & $\mathrm{ND}$ & $\mathrm{ND}$ & ND \\
\hline $\mathrm{pH} 7.00$ & 2 & ND & $\mathrm{ND}$ & $\mathrm{ND}$ & ND & ND & ND & ND & ND \\
\hline $\mathrm{pH} 8.00$ & 3 & ND & ND & ND & ND & $\mathrm{ND}$ & ND & ND & ND \\
\hline $\mathrm{pH} 9.00$ & 3 & ND & ND & ND & ND & ND & ND & ND & ND \\
\hline
\end{tabular}

See the note to Table 4. After adjustment of $\mathrm{pH}$ with $2 \mathrm{~N}-\mathrm{HCl}, 2 \mathrm{~N}-\mathrm{NaOH}$ or $25 \%$ phosphoric acid, the homogenate of $50 \mathrm{~g}$ mackerel muscle was distilled at $90^{\circ} \mathrm{C}$ for $30 \mathrm{~min}$. and volatile acids volatilized were measured. Fishy odor : 1=ordinary, 2=strong, 3=very strong.

pH 2 以下にすると比較的多種類の脂肪酸が量的にす多 く検出されたが, pH 4 以下ではすはや食品にはならな いので，実際の調理ではサバ肉からの揮発酸の揮発は極 微量であるといえる.

香辛料ではクローブ，調味料ではウスターソース，ト マトケチャップ, 白ワイン, 食酢などをサバ肉のホモジ ネートに添加することにより揮発する揮発酸が増加した。 これは，それら自身に含まれている揮発酸により揮発量 が増加するのと同時に，それらによって $\mathrm{pH}$ が低下す ることにより揮発酸が揮発しやすくなったためと考えら
れる. Table 2 のクローブ中に多量の酢酸が含まれて いるのが注目されるがくクローブから揮発する酢酸と思 われる物質について GC-MS で测定したところ，質量 数 $43 ， 45 ， 60$ に強いピークが見られ，酢酸であること が確認された)，これはクローブの香気成分であるオイ ゲノールの酢酸エステルが製造工程中に加水分解されて 生じたり，クローブの強い刺激を和らげるために人為的 に酸酸が添加されたためではないかと考えられる、香辛 料のうちローレルとオールスパイスで僅かに揮発量の減 少が見られたが，それ以外では揮発酸の揮発を㧕制する 


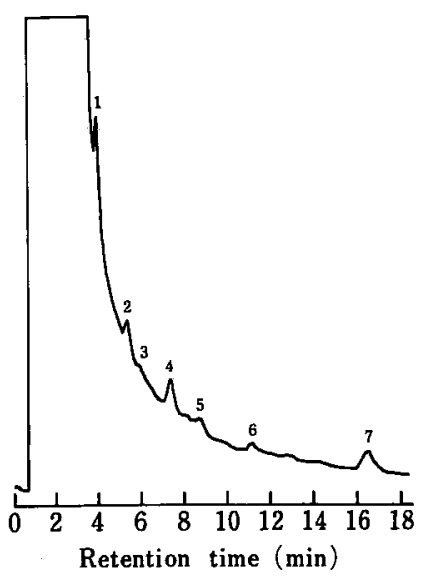

Fig. 3 Gas chromatogram of volatile acids extracted from mackerel muscle

Column : 10\% FON Celite 545 A, $3 \mathrm{~m}$, column temp. : $170^{\circ} \mathrm{C}$, injection temp. : $220^{\circ} \mathrm{C}$, carrier: $\mathrm{N}_{2} 50 \mathrm{ml} / \mathrm{min}$, detector : FID.

1. Acetic acid, 2. Propionic acid, 3. isoButyric acid, 4. $n$-Butyric acid, 5. isoValeric acid, 6. $n$-Valeric acid, 7.n-Caproic acid.

あのはみられず，揮発酸に関しては香辛料成分との反応 や結合による㧕臭効果はないと言える. また調味料です 赤味噌でわずかに揮発酸の揮発を抑制する効果がみられ たが，それ以外は全くそのような効果は見られず，香辛 料と同様のことが言える. ウスターソースや食酢などで $\mathrm{pH}$ が低下した状態ではイソ酪酸, イソ吉草酸, イソカ フロン酸などの分㞳した側鎖を持つ揮発酸が多く揮発す る傾向にあるが，分㞳した側鎖を持つ揮発酸の方が沸点 が低く揮発しやすいためと考えられる。

食品添加物では，アスコルビン酸とソルビン酸を添加 した場合に揮発酸の揮発量が増加しているが，これも $\mathrm{pH}$ 低下によるものと考えられる。，一方，バニリンやマ ルトールなどの着香料が揮発酸の揮発を㧕制しているの が注目されるが，これらの揮発酸に対する作用について はさらに詳細な検討が必要である．また魚臭の㧕制に効 果があるといわれているサイクロデキストリンは揮発酸 の揮発を㧕制する効果はみられず，揮発酸に対してはあ まり効果がないと考えられる。

魚臭強度は $\mathrm{pH}$ が高くなるほど強くなっているが， これは揮発酸などの酸性物質より揮発性アミンなどの塩 基性物質の方が魚臭への寄与度は高いためと考えられる。 しかし，揮発酸が他の臭気物質の匂いを強める作用をも
つといわれており ${ }^{10)}$ ，その理由として揮発酸が臭覚部位 の $\mathrm{pH}$ を低下させることにより嗅覚の感度を高めるた めではないかと考えられる。したがって微量であってす 魚臭に及ぼす揮発酸の影響は無視出来ないと考える。

\section{要約}

香辛料 18 種，調味料 9 種，食品添加物 9 種について 魚肉中の揮発酸の揮発に及ぼす影響を検討するため，サ

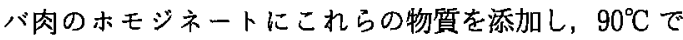
30 分間蒸留して揮発する揮発酸をガスクロマトグラフ ィーにより測定し，次の結果を得た。

1. 魚肉加ら揮発する揮発酸として，サケ，マグロ サンマ, カレイなどでは酶酸, プロピオン酸, $n$-酪酸, nーカプロン酸などが検出された．他の魚種ではほとん ど検出されなかった。

2. サバ肉に香辛料を添加した場合，クローブで酢酸 が多量（サバ肉 $50 \mathrm{~g}$ 当たり $112 \mu \mathrm{g}$ ）に揮発したが, クローブ中に含まれる酢酸によるるのと考えられる．そ の他の香辛料では検討したいずれの揮発酸す揮発しなか った.

3. サバ肉にウスターソース, 赤味噌, トマトケチャ ップ, 白ワイン，食酢などの調味料を添加した場合に揮 発酸が揮発したが，これらは調味料中に含まれる揮発酸 によるあのと考えられる。

4. サバ肉に食品添加物を添加した場合には，検討し たいずれの揮発酸も揮発しなかった。

5. サバ肉中に添加した 8 種の揮発酸の揮発に及ぼす 香辛料や調味料の影響については，香辛料ではローレル とオールスパイスで, 調味料では赫味噌で揮発酸の揮発 がわずかに抑制された，逆に香辛料ではクローブ，調味 料ではウスターンース，トマトケチャップ，白ワイン， 食酢を添加した場合に揮発酸の揮発量が増加した。 これ は調味料の添加によりホモジネートの $\mathrm{pH}$ が低下した ためと考えられる。

6. 同様に食品添加物としてアスコルビン酸とソルビ ン酸を添加した場合に揮発酸の揮発量が増加し，バニリ ンとマルトールでは隇少した．魚臭の抑制に効果がある といわれているサイクロデキストリンは揮発酸の揮発を 㧕制する効果がなかった。

7. 揮発酸の揮発に及ぼす $\mathrm{pH}$ の影響は非常に大き く, $\mathrm{pH} 6$ 以上ではサバ肉加揮発酸の揮発はほとんど 見られず， $\mathrm{pH} 5$ 以下では $n$-酪酸と $n$-カプロン酸の揮 発がみられ，pH 4 以下ではプロピオン酸やイン酪酸す 揮発した。 
付記本研究の要旨は日本農芸化学会昭和 61 年度 大会で発表した.

\section{文献}

1）川崎 健, 河端俊治, 長谷川彰 : 魚一その資源, 利用，経済，70，恒星社厚生閣，東京 (1980).

2）日本水産学会編：多獲性赤身魚の有效利用， 60 , 桓星社厚生閣, 東京 (1981).

3）太田静行 : 魚臭 - 畜肉臭, 182, 恒星社厚生閣, 東京 (1981).

4）太田静行 : 食品調味の知識, 235, 幸書房, 東京 (1975).

5）太田静行: 食品調味論, 212, 幸書房, 東京 (1976)

6）吉田秋比古・佐々木清司・岡村一弘 : 魚肉の嬌臭 試験 (第 1 報) 香辛料, 調味料および食品添加物 の魚臭に及ばす影響と揮発性了ミンに対する作用,
生活衛生, 27, 167 (1983).

7）吉田秋比古・佐々木清司・大柴恵一 : 魚肉の嬌臬 試験 (第 2 報) 香辛料，調味料および食品添加物 の魚臭に及ぼす影響と揮発性カルボニルに対する 作用, 生活衛生, 28, 211（1984）。

8）吉田秋比古・佐々木清司・大柴恵一：魚肉の嬌臭 試験 (第 3 報) 香辛料と食品添加物の魚臭に及ぼ す影響と揮発性カルボニルに対する作用（その2）, 生活衛生, 29, 142 (1985).

9）吉田秋比古・佐々木清司・大柴恵一：魚肉の嬌臭 試験 (第 4 報) 香辛料, 調味料および食品添加物 の魚莫に及ぼす影響と揮発性アミンに対する作用 (その 2), 大阪市立環境科学研究所報告調査・研 究年報, 48 (1986).

10）太田静行 : 魚臭 - 畜肉臭, 56, 恒星社厚生閣, 東 京 (1981).

(平成 2 年 8 月 16 日受理) 